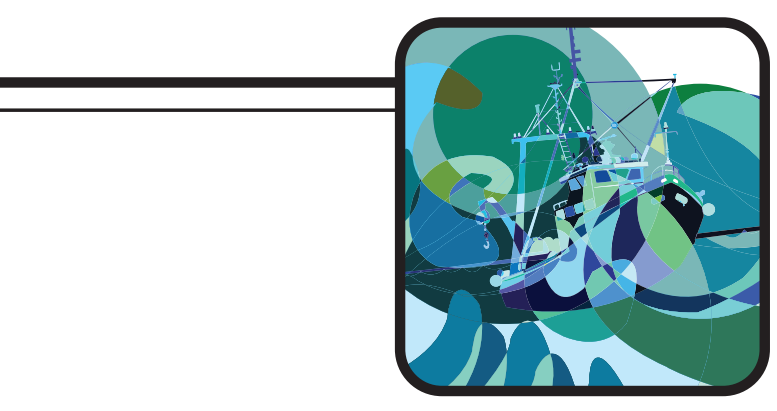

CHAPTER 5: Hundred and eighty years of fleet dynamics in the Belgian sea fisheries 


\section{CHAPTER 5. HUNDRED AND EIGHTY YEARS OF FLEET DYNAMICS IN THE BELGIAN SEA FISHERIES}

\section{Published as:}

Lescrauwaet, A.-K., Fockedey, N., Debergh, H., Vincx, M., Mees, J. 2012. Hundred and eighty years of fleet dynamics in the Belgian sea fisheries Rev. Fish Biol. Fish. Rev. Fish Biol. Fish. 23(2): 229-243.

hdl.handle.net/10.1007/s11160-012-9287-1Online first: 15 pp

\section{ABSTRACT}

Understanding the impact of fisheries on the commercial fish stocks requires detailed catch statistics and data on the dynamics of fleet and catch effort, at least before industrial fishing started. Most time series on the fleet dynamics start after the 1980s, at times when major changes in fleet characteristics had already taken place. In the present paper, the results of the integration of data on fleet size (from 1830), tonnage (from 1842) and engine power (kW, from 1912) of the Belgian sea fisheries fleet are presented. The decrease in fleet size and changes in overall tonnage and engine power since the beginning of the reconstructed time series, are quantified. The data show that the decrease in fleet size $(-85 \%)$ and in overall engine power $(-5 \%)$ was compensated by an increase in average tonnage per vessel ( $x 10$ increase) and in average engine power per vessel ( $x 6$ increase). The overall fishing effort of the fleet expressed as the total number of days spent at sea has decreased by approximately $-84 \%$ between 1938 and 2010, while the average amount of fish landed per day per vessel (1,000 kg in 2008-2010) has at least doubled in the same period. The data reconstruction provides a unique view on the dynamics in the sea fisheries fleet of Belgium over 180 years and the political and social events associated to these changes.

Keywords: Fleet dynamics, Historical reference, Belgium 


\subsection{INTRODUCTION}

\subsubsection{Sea Fisheries in BeLgIUM: A HISTORICAL PERSPECTIVE ON CATCH AND EFFORT}

The failure to manage fisheries sustainably in the present has triggered concern over 'shifting base-lines' in a marine ecology context (Pauly 1995, Pauly et al. 1998, Roberts 2007, Finley 2011) and stimulated research into the historical context of fisheries. The true nature of change in abundance of commercial fish species however can only be grasped if we take into account the impacts of fisheries at least since the onset of industrial fishing. In particular, time series of catch and effort before the widespread changes in fisheries towards the end of the 20th century are needed. In the absence of catch statistics, integrated and quality controlled landing statistics can be used as a proxy for fishing mortality and for further analysis related to the setting of historical baselines (Zeller and Pauly 2007, Lescrauwaet at al. 2010a). However, time-series on landings mostly date from after the start of intensive exploitation. Similarly, time series on fishing power and fishing effort typically do not go further back in time than 30-40 years. Hence, the currently available baselines for rebuilding depleted fish stocks typically refer to strongly exploited situations (Pitcher 2001) and reconstructions of historical time-series are needed to improve our understanding on the impacts of fishing. The North Sea was one of the first areas to adopt non-human mechanical power in fisheries. The invention of the steam engine and the appearance of the first steam trawler in the UK (1877) symbolize the start of industrial fishing, which started in Belgium with the arrival of the first steam trawler in Oostende in April 1884 (02/04/1884, the 'Prima 071').

The Belgian coast is $67 \mathrm{~km}$ long and located in the province of West-Flanders in the region of Flanders, Belgium (Figure 5.1.). Today, Belgium has four coastal ports (Nieuwpoort, Oostende,Zeebrugge and Blankenberge), although historically the fishing communities of Heist, Blankenberge, De Panne, Oostduinkerke and Koksijde, and the locations along the Scheldt estuary harboured an important number of vessels. Besides the fish auctions located in Oostende, Zeebrugge and Nieuwpoort (Figure 5.1.) there are no other dispersed landing points today. In 2011, the Belgian commercial sea fishing fleet counted 89 ships, with a total engine capacity of $44,025 \mathrm{~kW}$ and gross tonnage of 15,733 GT (Anon. 2012). 46 vessels are part of the Small Fleet Segment (max $221 \mathrm{~kW}$ engine power) of which 2 use passive gear. The remainder 43 vessels of the Large Fleet Segment have an engine power between $221 \mathrm{~kW}$ and a maximum of $1,200 \mathrm{~kW}$. This fleet segment consists of 5 vessels using trammel nets, 4 using otter trawl and 34 large beam trawl vessels ( $\geq 662 \mathrm{~kW}$ ). The Belgian fleet is highly specialized: more than $68 \%$ of the effort (days at sea) and $77 \%$ of total landings is achieved by beam trawlers (Anon. 2012) focusing primarily on flat fish species such as plaice (Pleuronectes platessa) and sole (Solea solea). The landings represent a total value of $€ 76$ million, of which $€ 65$ million are sold in Belgian ports, $€ 11$ million in foreign (mainly Dutch) ports. Sole generates $48 \%$ of the current total value of fisheries in Belgium (Anon. 2008). In 2010, the Belgian fleet landed a total of 19,683 tonnes (t), of which 15,970 $t$ were landed in the Belgian ports (Anon. 2012).

Around the turn of the $19^{\text {th }}$ century major changes took place in the Belgian fleet, as it moved from sailing vessels (with trawl and drift nets) and rowing boats (mainly passive gear) to steam vessels (with otter trawls) and later on the diesel engine powered vessels mainly deploying beam trawls (Hovart 1994) in particular from the 1960s.

Lescrauwaet et al. (2010a) addressed the absence of historical time-series on sea fisheries production in Flanders (Belgium) at the species level by conducting a data rescue and integration (Lescrauwaet et al. 2010b) reaching back to the beginning of the $20^{\text {th }}$ century. The authors quantified an overall decline of $75 \%$ in the total landings since the peak in 1947 and provided trends by species and by fishing area from 1929 till the present. From an environmental perspective however, trends in landings and catch statistics need to be interpreted in the context of fishing effort and fishing power, shifts in targeted species and fishing grounds (Kerby et al. 2012) and considering economic and political drivers. Therefore, the dynamics of the fishing fleet and the increase in fishing power which started at the end of the $19^{\text {th }}$ and continued throughout the $20^{\text {th }}$ century (motor engines, beam trawling, tickler chains, 
geographic positioning systems etc.) need to be quantified as a first step towards interpreting trends in fish landings statistics. In the current paper, the results of a historical reconstruction of the size and capacity of the Belgian sea fishing fleet (1832 until present) are presented and trends are described.

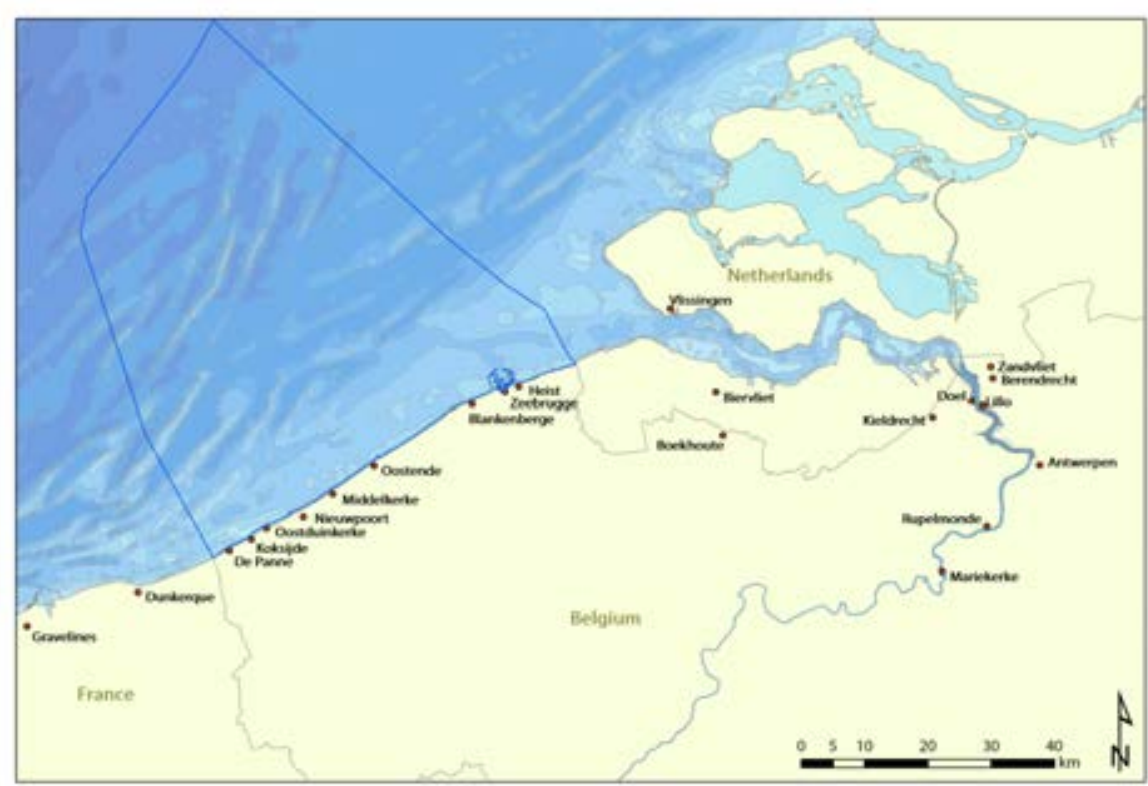

Figure 5.1. Map of the Belgian coast with the coastal (fishing) ports and auctions, including historical fishermen's settlements in Flanders, and the ports of Gravelines and Dunkerque in France. The line indicates the boundaries of the Belgian part of the North Sea. Source: a century of Sea Fisheries in Belgium (VLIZ 2009).

\subsection{Methodology}

A number of independent data sources were used to reconstruct the characteristics of the Belgian fleet from 1830 onwards. First, the annual 'Official list of the Belgian fishing vessels' OLBFV (section 5.2.1) is published by the Ministry of Transport (federal government of Belgium) since 1929. The second important source consists of statistical tables (1944-present) published by the National Institute of Statistics NIS (5.2.2) in cooperation with the Ministry of Agriculture and Fisheries. The information in the statistical tables is continued in the current annual series 'Landings and value of landings' and 'Analysis of the economic efficiency of the fleet' published by the department of Agriculture and Fisheries (Flemish government) until today. Before 1929, data were obtained from different disperse and fragmented sources (Table 5.1.).

\subsubsection{Ministry OF TRANSPORT, ANNUAL FleEt STATISTICS}

The data on fleet size, engine power, capacity and technology to reconstruct the history of fishing power and catch efficiency for the Belgian sea fisheries fleet is largely based on 'ship-by-ship' information. Since 1929 the Belgian Ministry of Transport publishes annual reports on the state of the national fleet, with separate lists for the fishing fleet. The annual 'OLBFV' describe characteristics of individual vessels by port of registration, identifying their immatriculation number, total length (TL), capacity as gross and net tonnage (register ton - RT or tonnage T), 
engine power (Kilowatt-kW or Dutch Horsepower-HP), owner (name, address), year of construction, ship wharf, construction material (wood, steel), fishing gear, and - however in less complete records- presence of some technological equipment (VHF, sonar, etc.). The data from the original paper copies were digitized (28,000 individual records) standardized and integrated in the 'Belgian fleet' database (Lescrauwaet et al. 2010c) as part of the HiFiDatabase (Lescrauwaet el al. 2010b). Integration efforts focused on the reconstruction of the 'lifeline' of individual ships, while standardisation was mainly centered on units of power and of proper names. The series starts in 1929, coinciding with the first detailed and formalized reporting on fish landings (Lescrauwaet et al. 2010b). For more information on the 'Belgian fleet' database and to consult information by individual ship, access the online search tool: http://www.vliz.be/cijfers beleid/zeevisserij/fleet.php

\subsubsection{Ministry of Agriculture ANd Fisheries, ANNUAL Agriculture Statistics}

A second time-series (1944 to present) was constructed based on governmental statistics published as the statistical tables $\mathrm{V}$ and $\mathrm{VI}$ (extent and activity of the fishing fleet, by port, by class of gross tonnage) in the 'Agriculture statistics' (Landbouwstatistieken), which also report on fishing effort, landings and their values. These tables contain aggregated reports on total number and overall capacity (gross tonnage) of vessels by fishing port, number of vessels by category of engine power, for steam powered ( 2 categories) and motor engines ( 5 categories). Advantage of this data is the reference to fishing effort and landings. Fishing effort is expressed as days at sea (SD) and days fishing. A day at sea is defined as any continuous period of 24 hours (or part thereof) during which a vessel is present within an area and absent from port. Disadvantage of this second source is the level of aggregation, the discontinuity in category boundaries, and the restricted time coverage (starting in 1944). Also, the tables refer to the active fleet only and do not include the 'open and half-open' ships. Although the latter contributed less in overall gross tonnage of the fleet, they were important in number at least in the beginning of the time-series. This second database was used as a control to the first and more detailed 'Belgian fleet' database.

\subsubsection{AdDitional SOURCES}

Additional data and information on the fleet were obtained from punctual historical surveys, publications and reports commissioned by authorities to provide input e.g. the report of the commission in charge of studying the situation of fisheries in Belgium in 1866 (Chambre des Représentants 1866) to provide advice to the authorities on the question of abolishment of subsidies, and the thorough survey conducted by De Zuttere (1909).

The data integration covers the period from 1830 to present. An overview of sources is included in table 5.1. For a detailed description of the digitization, standardization procedures and quality control, the authors refer to Lescrauwaet et al. (2010b). Our literature screening indicated that structurally embedded reporting on the fleet size and features in Flanders (Belgium) started in 1929 with a good level of consistency and continuity ever since then. Much like our findings on historical landings - with the exception of the annual reports on Belgian sea fisheries landings that are electronic formats (pdf or html) from 1998 onwards - none of the data contained in the pre-1998 sources were available in electronic format or available for overviews or research analysis. As is the case for reported landings of fish and fish products, the beginning of structural reporting on the fleet coincided with the period where most states in Europe developed a statistics approach to underpin policy development (Lescrauwaet et al. 2010a). 
Table 5.1.: Overview of sources used for the reconstruction of time-series on the Belgian fishing fleet

\begin{tabular}{|c|c|c|}
\hline Period & Fleet parameters & Source \\
\hline $1830-1841$ & $\begin{array}{l}\text { Number of ships for the port of Oostende; total } \\
\text { tonnage of ships for the port of Oostende }\end{array}$ & $\begin{array}{l}\text { Rapport de la Commission chargée de faire une enquête sur la } \\
\text { situation de la pêche maritime en Belgique. Séance du } 17 \text { mai } \\
\text { 1866. Chambre des Représentants: Bruxelles. XLII, } 75 \text { pp }\end{array}$ \\
\hline $\begin{array}{l}1832,1836 \\
1839\end{array}$ & $\begin{array}{l}\text { Number of ships for the ports of Nieuwpoort, } \\
\text { Blankenberge, Heist, De Panne/Adinkerke, } \\
\text { Koksijde/Oostduinkerke. }\end{array}$ & Rapport de la Commission 1866 see above \\
\hline $1842-1864$ & $\begin{array}{l}\text { Number of ships by port (Oostende, } \\
\text { Nieuwpoort, De Panne/Adinkerke, } \\
\text { Koksijde/Oostduinkerke, Blankenberge, Heist); } \\
\text { total tonnage of ships by port (all ports) }\end{array}$ & Rapport de la Commission 1866 see above \\
\hline $1865-1871$ & No data & No sources \\
\hline $\begin{array}{l}1872,1877 \\
1882,1887 \\
1892-1903\end{array}$ & $\begin{array}{l}\text { Number of ships by port, including number of } \\
\text { steam trawlers; total tonnage of ships by port; } \\
\text { open and half-open vessels for } 1892-1911 \\
\text { estimated based on punctual reported numbers } \\
\text { for } 1892 \text { and } 1905\end{array}$ & $\begin{array}{l}\text { Hoek, P. and Kyle, H. (1905) Appendix J: Statistics of the North } \\
\text { Sea fisheries. Part I: The fisheries of the various countries. } \\
\text { Belgium Rapp. et Proc.-Verb. Cons. Int. Explor. Mer 3: 82-91 }\end{array}$ \\
\hline 1905 & $\begin{array}{l}\text { Number of ships by port, including number of } \\
\text { steam trawlers; Total tonnage of ships by port, } \\
\text { including tonnage of steam trawlers }\end{array}$ & $\begin{array}{l}\text { De Zuttere, C. (1909) Enquête sur la pêche maritime en } \\
\text { Belgique: introduction, recencement de la pêche maritime. } \\
\text { Lebègue \& cie: Bruxelles. } 634 \mathrm{pp}\end{array}$ \\
\hline 1910 & $\begin{array}{l}\text { Number of ships by port, including number of } \\
\text { steam trawlers; total tonnage of ships by port, } \\
\text { including tonnage of steam trawlers. }\end{array}$ & $\begin{array}{l}\text { Von Schoen, F. (1912) La pêche maritime de la Belgique } \\
\text { Bulletin de la navigation et des pêches maritimes 14: 185-205 }\end{array}$ \\
\hline 1911-1931 & $\begin{array}{l}\text { Number of ships by port, including indication of } \\
\text { number of steam trawlers; total tonnage of } \\
\text { ships by port, including indication of tonnage of } \\
\text { steam trawlers. }\end{array}$ & $\begin{array}{l}\text { Provincie West-Vlaanderen. Commissie voor Zeevisscherij } \\
\text { Jaarverslag der Commissie voor Zeevisscherij. Druk. Verbeke- } \\
\text { Loys: Brugge: 1912, 1913, 1919-1931. }\end{array}$ \\
\hline $1929-2011$ & $\begin{array}{l}\text { Number of ships by port; tonnage in GRT until } \\
1983 \text {, in GRT and GT between } 1984 \text { and 1994, in } \\
\text { GT from } 1994 \text { onwards, HP, kW, total length, } \\
\text { total width, ownership and other ship-by-ship } \\
\text { information }\end{array}$ & $\begin{array}{l}\text { Officieele lijst der visschersvaartuigen. Ministerie van } \\
\text { Landbouw. Dienst voor Zeevisscherij: Oostende (and continued } \\
\text { series): 1929-2010 }\end{array}$ \\
\hline $2008-2010$ & $\begin{array}{l}\text { Number of ships by port; total tonnage (GT) of } \\
\text { ships by port }\end{array}$ & $\begin{array}{l}\text { Tessens, E. and Velghe, M. (2008) De Belgische zeevisserij: } \\
\text { aanvoer en besomming 2008. Vlaamse Overheid. Departement } \\
\text { Landbouw en Visserij. Afdeling Landbouw- en Visserijbeleid. } \\
\text { Zeevisserij: Brussel. } 103 \mathrm{pp} \\
\text { Tessens E and Velghe M (2010) De Belgische zeevisserij: } \\
\text { aanvoer en besomming 2009. Vlaamse Overheid. Departement } \\
\text { Landbouw en Visserij. Afdeling Landbouw- en Visserijbeleid. } \\
\text { Zeevisserij: Oostende. } 109 \mathrm{pp} \\
\text { Anon. (2012). FIVA Activiteitenverslag } 2011 .\end{array}$ \\
\hline
\end{tabular}

Metadata are rarely provided in historical sources. Graphical analysis of the result of the integration of the data extracted from fragmented sources and covering different periods uncovered two main breaks in the observed trends. A first break was identified in the total number of ships reported for Oostende in 1892-1911. Literature study (Hoek and Kyle 1905, Commissie voor Zeevisscherij 1912, 1913 and 1919-1931) confirmed that 'open and half-open vessels' were not included in the total number for this period, whereas they were identified and included in the data from OLBFV (time-series after 1929). An estimation of 'open and half-open' vessels for the period 19821911 was included based on reported numbers for 1892 and for 1905 as anchor points (Table 5.1.). Graphical analysis uncovered a second important break in the integrated time-series on tonnage. Historically, different 
measurements to calculate vessels cargo capacity were in place in different countries. The standardised system of gross register ton (GRT) became British law in 1854. In Belgium GRT was established in 1876 and transcribed in Belgian law as Royal Decree in December 1879. In practice however, both the GRT and the cubic volume $\left(\mathrm{m}^{3}\right)$ coexisted for administrative purposes in Belgium. GRT was established internationally by the Convention for a uniform system of tonnage measurement of ships, signed in Oslo in 1947. Subsequently, the system of gross tonnage (GT) was defined by the International Maritime Organization in 1969 and it came into force on July 18, 1982. Gross tonnage is an index related to a ship's overall internal volume. It is calculated by using the formula $\mathrm{GT}=\mathrm{K}^{*} \mathrm{~V}$, where $V=$ total volume in $\mathrm{m}^{3}$ and $\mathrm{K}=0.2+0.02 * \log 10 \mathrm{~V}(\mathrm{~K}$ is a figure between 0.22 and 0.32 ) depending on the ship's size. GT is therefore tied to the cubic meter unit of volumetric capacity, but it is a unit-less entity. Although the time-series on tonnage was standardised to obtain coherence over time, problems persist with the data on tonnage for the early years for which metadata is very scarce.

\subsection{RESULTS AND DISCUSSION}

During the period of the French Republic (1795-1814) the province of West-Flanders was under the French administration of the 'Departement de la Lys-Leie'. Due to the political turmoil and wars, Flemish fishermen were often recruited and fisheries could not prosper as they did during the Austrian empire (1713-1795). During the Austrian period Flemish fisheries flourished thanks to the establishment of direct subsidies and indirect tax levies on imported fish. Between 1815 and 1830, the Flemish provinces became part of the United Kingdom of the Netherlands. As soon as 1816 the administration in Brussels issued a system of subsidies to stimulate fisheries, however this system did not take into account the particular fishing gears and techniques used in Flanders. The Flemish fisheries therefore could not fully qualify to receive the subsidies that favoured the fisheries in the northern Dutch provinces (De Zuttere 1909).

With the independence of Belgium in 1830, the Dutch system of subsidies was adjusted to the conditions of the Flemish fisheries for salted herring and cod, by a complex system of laws e.g. the Law of 27/05/1837 to promote national fisheries, or the Law to assign credits and subsidies to promote national fisheries (XLI(132): 411; http://www.vliz.be/imis/imis.php?module=ref\&refid=203467). An interesting side effect of this system of subsidies was the setting up of detailed statistics on the fleet and fishing effort, since the payment of subsidies throughout this period (1836-1866) was subject to reporting. In summer, Belgian fishermen travelled to the Dogger Bank, the Faroe Islands, the Shetland Islands and the Icelandic Sea for cod fishing, mainly from the ports of Oostende, Nieuwpoort and Antwerpen. In the winter there was also a smaller number of vessels travelling from Nieuwpoort and Antwerpen to the Doggerbank to catch cod (Chambre des Représentants 1866). The landings of fresh fish at that time were not subject to subsidies and reporting, although the overall income value was recorded (in Belgian francs BEF). Fresh fish fisheries were restricted to inshore or coastal waters and during the winter months (Poppe 1977). The introduction of creels (seawater tanks within the ship's hold) in 1820 and the use of artificial ice from 1874 were important steps to improve quantity and quality of the fresh fish landings. The combined introduction of the steam engine vessels (1884), the employment of otter trawl nets (1894) and the use of donkeys (1882) to raise the heavy trawl gear mechanically, were technological improvements which allowed a significant increase in catches and profits and a fast expansion of the fresh fish fisheries towards new fishing grounds (Vanneste and Hovart 1959). From 1905, steam trawlers moved offshore Portugal and Spain and in 1908, the first Belgian trawlers reached the White Sea. Another important renewal in the fishing industry was the application of an auxiliary engine from 1910 (Vanneste and Hovart 1959) and finally the widespread introduction of the motor engines after the Second World War (WWII, 1939-1945). 


\subsubsection{TREND IN TOTAL NUMBER OF FISHING VESSELS OF THE BELGIAN FISHING FLEET SINCE 1830}

The data integration covers the period from 1830 to 2010. In spite of the data gaps (1865-1871 and 1915-1918, Table 5.1. and Figure 5.2.) and the inter-annual differences in coverage of ports and types of vessels, the timeseries reconstructs the overall trend in total number of fishing vessels. From the beginning of reporting, the total number of vessels increased from 145 in 1832 to 274 in 1864, nearly duplicating in 3 decades (Figure 5.2.). This increase was explained by De Zuttere, who was a member of the government commission of 1866, as a direct effect of the system of subsidies (see above). Oostende remained the most important port throughout this period and the next period of reporting (1892-1911, Figure 5.2.), as it was more apt to receive larger vessels. The facilities of the new port of Zeebrugge were inaugurated in 1907. The fishing port of Nieuwpoort, the settlements of Heist and Blankenberge to the east, and De Panne/Adinkerke and Oostduinkerke/Koksijde to the west also harboured an important number of vessels. Most of these stranded on the beaches to disembark the produce, or used the neighbouring ports of Nieuwpoort, Blankenberge and later Zeebrugge to do so. By the end of the 19th century, Oostende increasingly focused on 'fresh fish' catches during winter, in particular with the appearance of steam trawlers from 1884-1887 onwards. De Panne/Adinkerke, Oostduinkerke/Koksijde, Heist and Blankenberge were home to vessels of coastal fisheries and fishing areas at shorter distances.

A maximum total number of 630 fishing vessels was reported in 1913 (Commissie voor Zeevisscherij 1913), at the outbreak of the First World War (WWI, 1914-1918). At the eve of WWI, the new port infrastructure of Zeebrugge was harbour to 20 sailing vessels, Oostende to 327 of which 29 steamers, followed by De Panne (87), Heist (67), Blankenberge (67), Nieuwpoort (37) and Oostduinkerke/Koksijde (26).

While the fleet size quickly recovered from the destruction suffered during WWI, a revolution took place in fishing power of the fleet as they moved from sail or steam as driving power, to motor engines during the inter-war period (1919-1939). Motors were first installed as donkeys (to lift the nets) and as auxiliary power (propelling power) on sailing vessels and progressively as central driving power (Commissie voor Zeevisscherij 1912, 1913, 1919-1931) (Figure 5.5. and section on driving power and tonnage).

These shifts also required considerable investments and after WWII, fishing moved from a more family-oriented business to shipping companies. Fishing activities became concentrated around only 4 (Oostende, Zeebrugge, Nieuwpoort, Blankenberge) of the previously mentioned ports or fishing communities.

The fish stocks in the North Sea showed a recovery after the cessation of the fishing activities during WWII and a historic maximum of 75,370 tonnes (in 1947) was reported in overall landings of the Belgian sea fisheries. However, the sector was severely hit by an economic crisis in 1948 and by 1950 the North Sea showed marks of depletion again. In only 10 years time, the fleet size decreased from approximately 550 to 450 vessels (-20\%). The larger otter trawling vessels were forced to shift their fishing activities to the Icelandic waters to ensure profitability. By 1958, the landings from the Icelandic Sea represented $40 \%$ of all fish disembarked by Belgian fishermen (Lescrauwaet et al. 2010a). Another segment of the fleet targeted the rich concentrations of flatfish (mainly sole) on the White Bank (eastern part of the central North Sea). When the catches of sole decreased on the White Bank after 1955 the Belgian fisheries returned to the western fishing grounds (South-West Ireland, Bristol Channel), which they had left 10 years before in favour of the North Sea. 


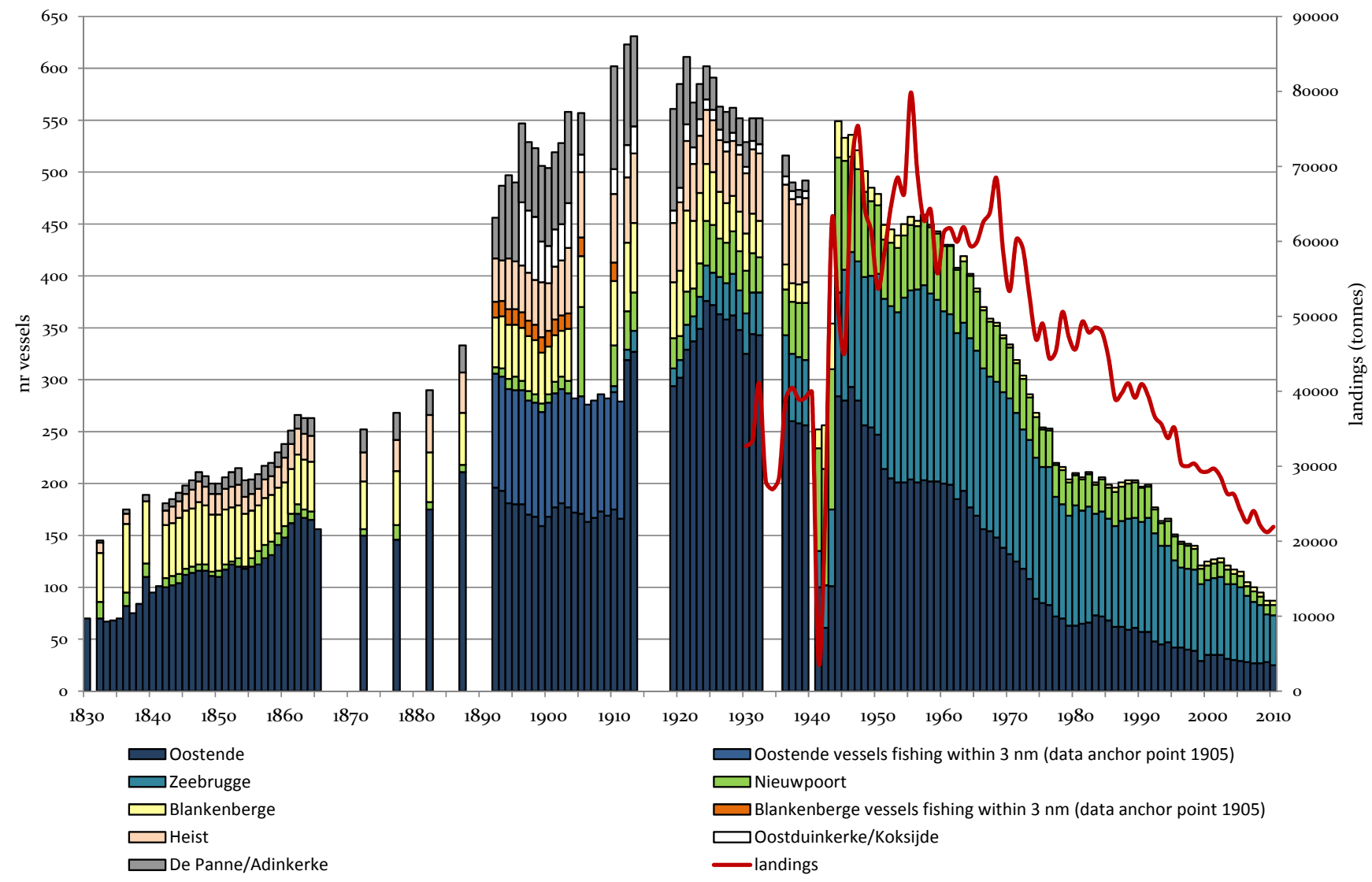

Figure 5.2.: Trend in number of vessels of the Belgian fishing fleet in the period 1830-2010. Source: VLIZ HIFIDatabase, reconstructed from historical sources Table 5.1.

In the 1960s, major structural changes took place in the Belgian sea fisheries fleet. The large shipping companies which had invested in steam trawlers disappeared (e.g. the Ostend Shipping Company): the last Belgian steam trawler sailed out to England on the 14th of January 1964 exactly eighty years after the first steam trawler entered in the port of Oostende. Between 1961 and 1969, governmental subsidies were issued for the renewal of the fleet with bounties for the demolition of older ships and for the purchase of new steel hulled medium-sized motor trawlers (Poppe 1977). Although the beam-trawl was introduced in 1822 in Oostende, it went nearly unnoticed until the 1960s. In 1959, the paired beam-trawl fishery ('bokkenvisserij', a ship pulling one beam-trawl on each side of the vessel) was implemented from the port of Zeebrugge: first for the brown shrimp (Crangon crangon) fisheries, and later also for the sole fisheries. Also from Zeebrugge, succesful ventures for pair-otter trawl ('spanvisserij', two ships pulling one otter trawl) fisheries for cod were implemented which increased the relative importance of Zeebrugge as fishing port. Whereas the port of Oostende had kept its reputation of first fishing port since at least the 18th century (Cloquet 1842, De Zuttere 1909) Zeebrugge definitely took over in 1968 as the most important port in terms of fleet size and in 1985 in terms of landings. 
Between 1960 and 1975 the gradual decline in the overall fleet size, from 430 to approximately 250 vessels (-42\%), was particularly evident in the port of Oostende with a decrease of $-58 \%$ (from 200 to 85 ). The traditional fisheries from Oostende were further affected in 1972 because access to the distant and rich fishing grounds became restricted for all foreign fishing fleets when Iceland demarcated its territorial waters from $12 \mathrm{~nm}$ to $50 \mathrm{~nm}$. From 1975 the presence of Belgian fishermen within the declared $200 \mathrm{~nm}$ exclusive economic zone of Icelandic, became subject to a 'phase-out'. As a consequence of the loss of the Icelandic waters towards 1980, Belgian vessels shifted their activities again towards the central part of the North Sea (Omey 1982) and - to a lesser extent - towards the English Channel, Bristol Channel, South and West Ireland and the Irish Sea. The gradual decline in the total number of vessels continued and in January 2011 the Belgian fleet that operates from coastal ports counts 87 ships. The structural changes as a consequence of technological developments in the 1960s, the loss of access to the Icelandic waters as fishing grounds, the energy crisis in the early 1970s and the increasing fuel costs, and the specific programmes of the European Commission Common Fisheries Policy oriented to the decommissioning of ships with the aim to reduce fleet capacity, have contributed in different degrees to this gradual decline in fleet size.

\subsubsection{FISHING PORTS AND VESSELS IN THE ESTUARY OF THE RIVER SCHELDT (1930-2010)}

Although the present paper focuses on reconstructing the landings and fishing capacity of the fleet operating from the coastal ports, time-series on the number of vessels operating from ports located along the estuary of the river Scheldt were also reconstructed on a ship-by-ship basis (Lescrauwaet et al. 2010c), many of which were small open or half-open decked boats. The Scheldt has a long tradition of inshore fisheries on the estuary in particular for brown shrimp and some flatfish species. However, historical data on landings from the Scheldt estuary are currently unavailable so it is not feasible to relate the landings to the fleet or its fishing effort.

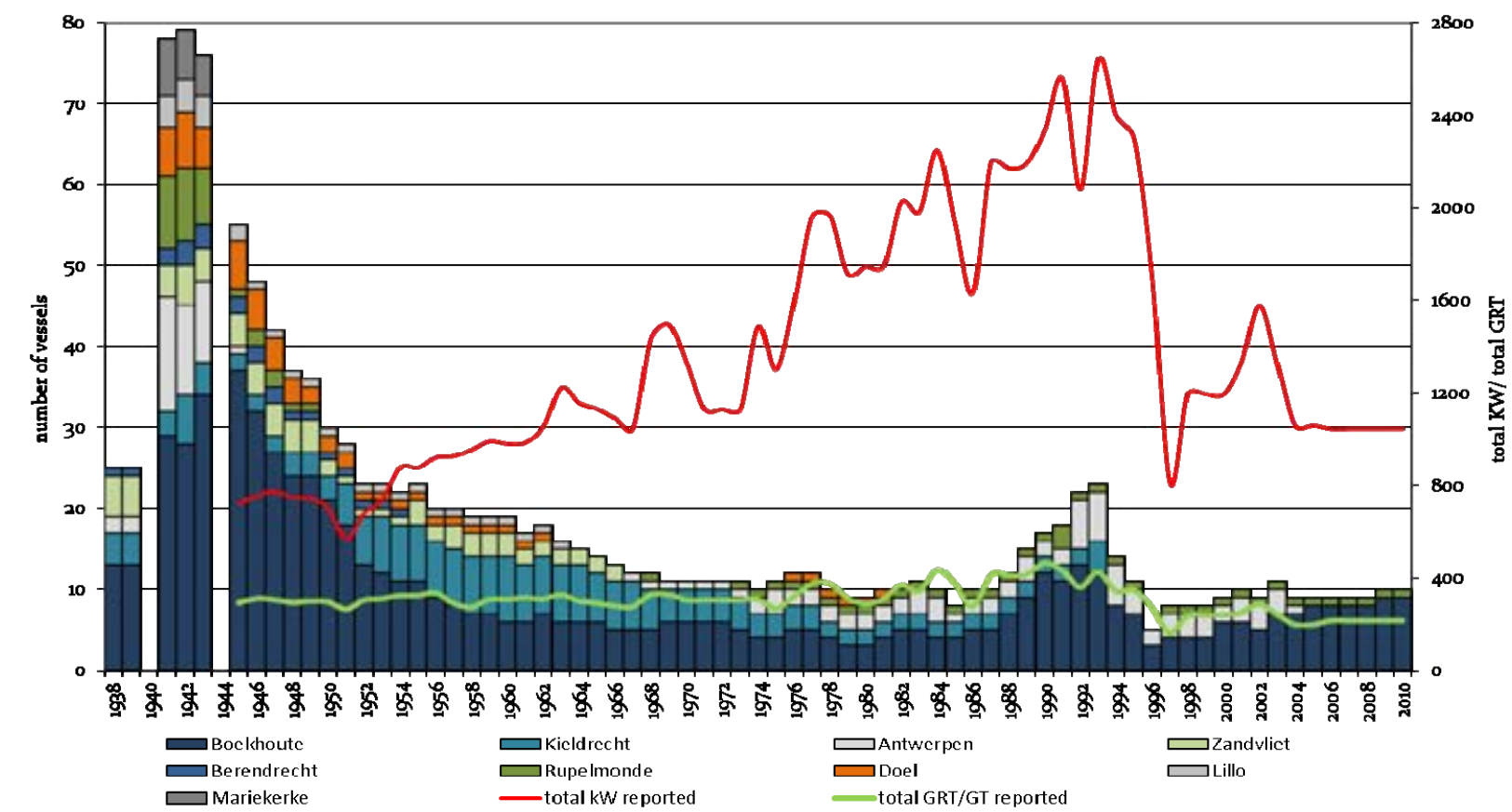

Figure 5.3.: Trend in number of vessels, total fishing power (kW) and Gross tonnage (GRT and GT) of the Belgian estuarine and inshore fishing fleet operating from ports along the river Scheldt in the period 1930-2010. Source: VLIZ HIFIDatabase, reconstructed from historical sources Table 5.1. 
Similar to the case for the coastal ports, the fleet on the Scheldt has declined from 79 in 1942 to less than 10 today and total fishing power ( $\mathrm{kW}$ ) is comparable to that of the 1960s (Figure 5.3.). More strikingly, 7 of the former 9 fishing ports and their fishing communities along the Scheldt estuary have disappeared e.g. Zandvliet, Mariekerke and Doel.

\subsubsection{TREND IN TOTAL TONNAGE OF THE FLEET AND AVERAGE TONNAGE OF FISHING VESSELS OF THE BELGIAN FISHING FLEET SINCE 1842}

The tonnage is a measurement of the overall volume of a ship's enclosed spaces. It is closely linked to the vessel's storage capacity and to its driving power (engine or sail), and is an expression of the ambition of a vessel's owner. In the past, the tonnage of a vessel in Belgium was expressed either in Moorsom ton, in Gross Register ton GRT, or in Gross Tonnage (GT) which applies to new ships from 1982 (section 5.2.). In Belgium, in practice, the first (2) ships measured according to the GT system were registered in the 1984 annual report. Before that, ships were reported as register ton GRT or in $\mathrm{m}^{3}$. From 1984 onwards these measurements were gradually replaced by GT as new ships entered the fleet or as older ships were gradually measured according to the GT system. From 1994, all ships measurements were expressed as GT. The data integration covers the period from 1842 to present and shows the same data gaps as in the reconstruction of the fleet size (Figure 5.2.).

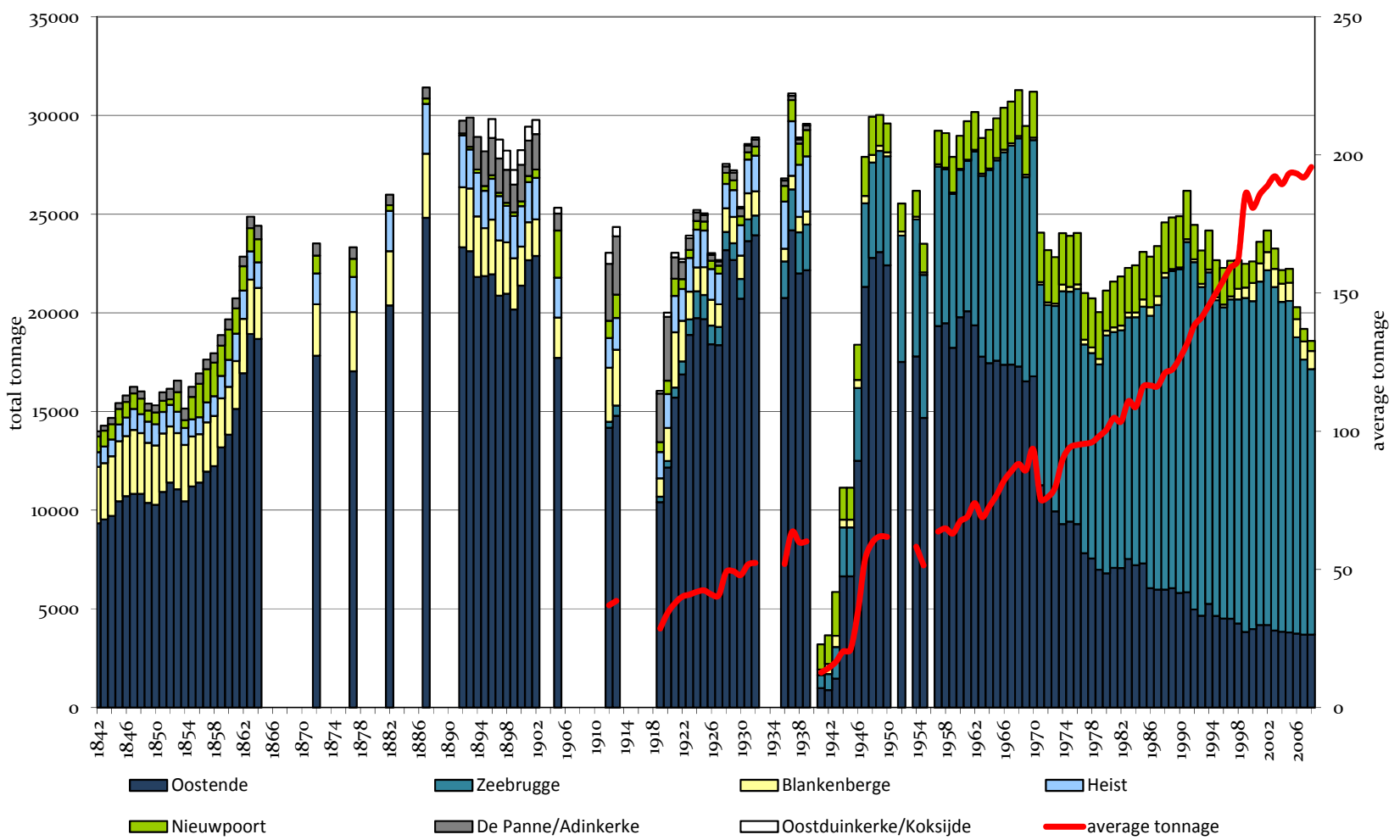

Figure 5.4.: Trend in total gross tonnage and average tonnage of vessels of the Belgian fishing fleet in the period 1842-2010. Source: VLIZ HiFiDatabase, reconstructed from historical sources Table 5.1. From 1984 to 1994, tonnage measurements were gradually replaced by the GT. After 1994 tonnage is expressed as the unit-less GT (see text). 
Overall gross tonnage of the fleet increased from 1842 to 1864 (Figure 5.4.), the period during which subsidies were granted by the government for new ship constructions (e.g. Royal Decree 07/01/1837) and for cod and herring fisheries (e.g. Royal Decree 19/06/1837). Average tonnage increased in Oostende and in Nieuwpoort, with offshore fisheries for cod and herring, whereas the other locations operated smaller vessels for inshore fisheries and short distances (Chambre des Représentants 1866).

The arrival of steam vessels in 1884 affected the overall nature of the fleet, in particular the average size of the sailing vessels. From 1884 until 1905 the tonnage decreased in all ports except in Oostende where the core of the fleet of steamers was located. The larger sailing vessels could no longer compete with the efficiency and haul-out of the large steamers and specialized in inshore fisheries (Commissie voor Zeevisscherij 1913). In 1912 the steamers represented $6 \%$ of the ships with covered decks (see also Fig. 5.5.), but contributed $25 \%$ of the total tonnage and $60 \%$ of the total fish production (reported in Belgian francs BEF). In particular just after WWI, when total tonnage had fallen substantially (16,043 GRT in 1919, Figure 5.4.), the recovery of GRT was most notorious in Oostende where steamers increased from 25 (4,899 GRT) in 1919 to 58 in 1926 (9,812 GRT). After WWI, total gross tonnage over all ports grew from 16,043 GRT in 1919 to 31,205 GRT in 1970, an increase interrupted only by the destruction of the fleet during WWII (Figure 5.4.). The reverse trend in Oostende however set in from the 1960s and is particularly visible at the beginning of the 1970s when a number of larger ships registered in this port were taken out of service and registered tonnage decreased from 16,800 GRT to 11300 GRT (-33\%). Meanwhile, the increase of the overall tonnage in the port of Zeebrugge - especially between 1980 and 1990 - could not compensate for the overall decline. Finally total tonnage dropped from 24,175 GT in 2002 to 15,812 GT in 2010. Although the fleet size has downsized to about $17 \%$ compared to the post WWII situation, the near 10 -fold increase in average tonnage, from approximately 20 GRT in 1945 and 70 GRT in 1950, to near 200 GT (approximately 277 GRT) in 2010, has partially compensated the overall decrease in tonnage of the fleet (Figure 5.4.).

\subsubsection{TREND IN TOTAL INSTALLED ENGINE POWER (KILOWATT-KW) OF THE FLEET AND AVERAGE ENGINE POWER (KW) OF FISHING VESSELS OF THE BELGIAN FISHING FLEET SINCE 1928}

The arrival of the first steam vessel in Belgium (Oostende 1884) triggered a period marked by major changes in the fishing power of the fleet, which until then had remained dependent on the sail as only driving force. In only 16 years' time (1912-1928) a major transition would take place. In 1912, 90\% of the fleet consisted of sailing vessels of which nearly half deployed a motorized donkey to haul out the nets (Commissie voor Zeevisserij 1913, Figure 5.5.). In 1928 however, 10 years after WWI, this segment of the fleet represented only 5\%. Figure 5.5. shows the evolution in total number of the fleet before and after WWI and the major changes in numbers (Figure 5.5. data table) and proportion (Figure 5.5.) for the different types of driving force of the fleet. In 1928, 95\% of the vessels (not including the smaller 'open and half-open' vessels) were using (auxiliary) motor or steam engines (14\% from the total) as driving force. 


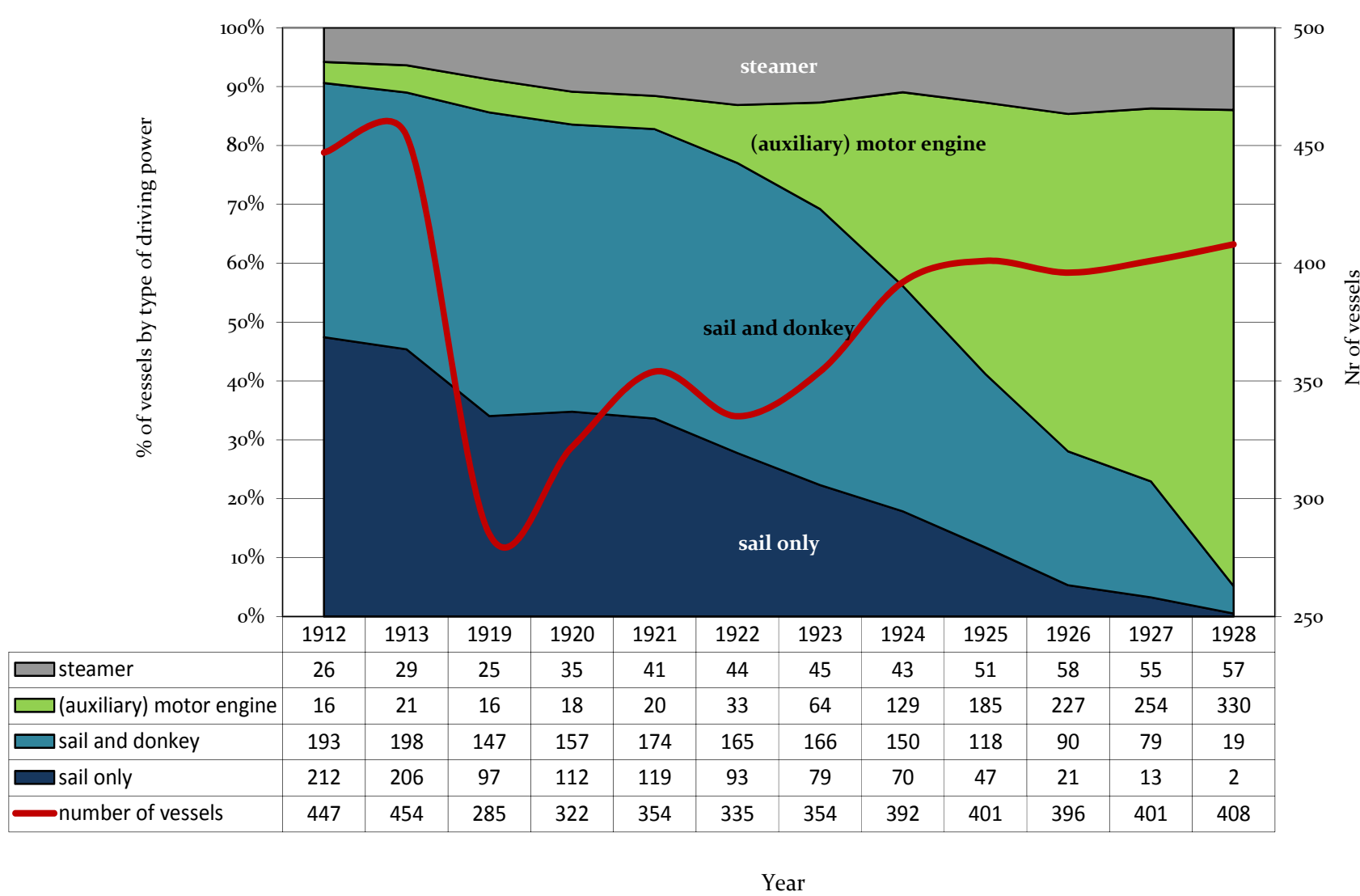

Figure 5.5.: Change in driving force (1912-1928) of the Belgian fishing fleet by type of driving force: sailing vessels with 'sail only', sailing vessels using donkeys to haul out the nets 'sail and donkey', vessels with motors or auxiliary motors, and steam vessels. The figures in the graph are expressed as \% of the total fleet size (left axis); the red line and the data table give absolute numbers. Data reconstructed from historical sources listed in Table 5.1. Note: data in the table do not include 'open and halfopen' decks, only vessels with closed-covered decks.

The reconstruction of the time-series of engine power (Horsepower HP and/or Kilowatt kW, Figure 5.6.) is based on the OLBFV from 1928 until present, covering a period with comparable fleet characteristics (>95\% of the fleet is motorized in 1928). Engine power was reported in sources as 'effective Horsepower' or in kilowatt, integrated on a ship-by-ship basis and standardized to Kilowatt ( $1 \mathrm{HP}=0,745699 \mathrm{~kW})$. The engine power measurements were provided by the Maritime Inspection and reported as 'effective engine power', which differs from the theoretical engine power by taking into account the friction losses. As a general note however, the statistics on engine power must be interpreted with care since declared engine power may differ from true installed engine power, because of taxes or licensing issues. 


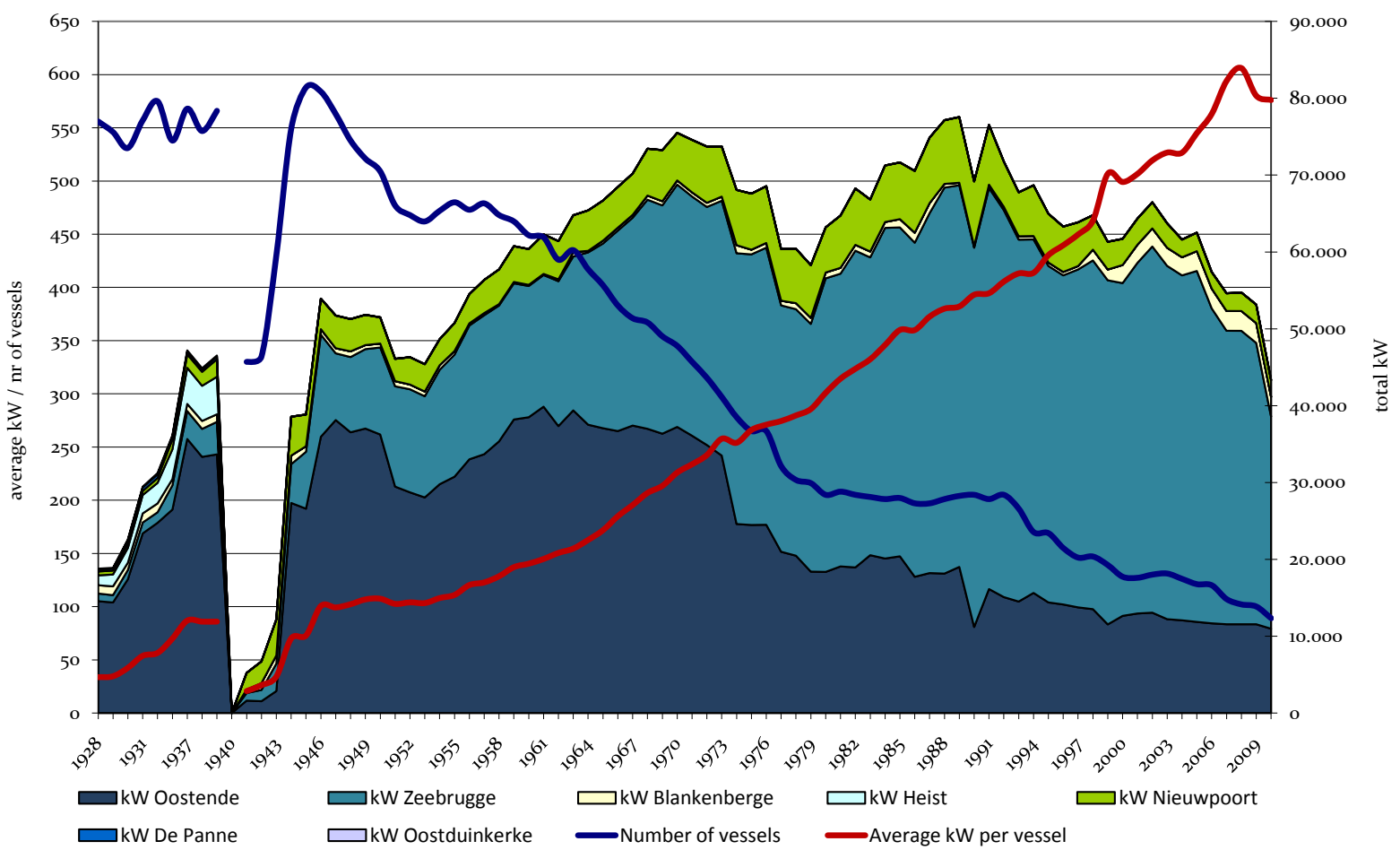

Figure 5.6.: Trend in total installed motor capacity (Kilowatt kW) of the Belgian fleet, by port, and average installed engine power of vessels in the period 1928-2010. Source: VLIZ HiFiDatabase reconstructed from Official List of the Belgian fishing vessels on a ship-by-ship data integration.

Total installed Kilowatt (kW) of the fleet amounted to 54,000 kW in 1946 compared to 51,200 kW in 2011 (Figure 5.6., figures in the text are rounded). Peaks in total engine power of the fleet were reached in $1970(75,500 \mathrm{~kW})$ and in 1989 (77,500 kW). Whereas the total kW of the fleet in Oostende reached a maximum of 39,800 kW in 1961 and decreased since then, total kW in Zeebrugge increased up to 52,100 kW in 1991 before declining (Figure 5.6.). In summary, in 2011 a fleet size of only $15 \%$ of the size of 1946 operated a total engine power of $95 \%$ compared to that of 1946. In opposite wording, the fleet size decreased by $85 \%$ while overall engine power decreased by $5 \%$ only. On average, a fishing vessel has become 5.7 times more powerful in terms of engine capacity compared to 1946. This comparison does not take into account other relevant enabling technologies that have significantly enhanced fishing power, and are commonly referred to as 'technological creep'. Marchal et al. (2003) estimated an annual increase in catchability as a consequence of 'technological creep' of up to $10 \%$ in North Sea surveys, while Rijnsdorp et al. (1996) reported an annual increase of 1.8-2.6\% in beam trawl fisheries for sole and plaice in the North Sea. For the case of the Belgian fleet, this increase in average engine power is related to the subsidised (re)introduction of the beam trawl in the 1960s and to the introduction of tickler chains (an example of technological creep) rigged in the net-mouth and which required more engine power (Polet et al. 1998).

This positive trend in average tonnage (GRT or GT) and average engine power (kW) in a declining fleet size was legally capped by measures establishing a maximum of 1,200 kW per vessel, and a maximum of $221 \mathrm{~kW}$ for beam trawlers fishing within the 12-miles territorial waters. The decline in total engine power $(\mathrm{kW})$ in recent years is both due to the decline in the fleet size and the gradual replacement of larger vessels by smaller ones. 


\subsubsection{TREND IN EFFORT OF THE FLEET: NUMBER OF DAYS SPENT AT SEA AND FISHING SINCE 1938}

Figure 5.7. shows the evolution of the total number of days the fleet spent at sea or days spent fishing. The annual number of days spent at sea by the entire fleet has decreased from approximately 91,800 in 1938 to 15,100 days in 2010 (-84\%, Figure 5.7.). Crews spent on average $88 \%$ of the days at sea as effectual fishing days, and a vessel spent on average 171 days per year at sea. Only during WWII, when fishing was allowed during daytime breaks and in coastal waters, a day spent at sea was actually spent fishing.

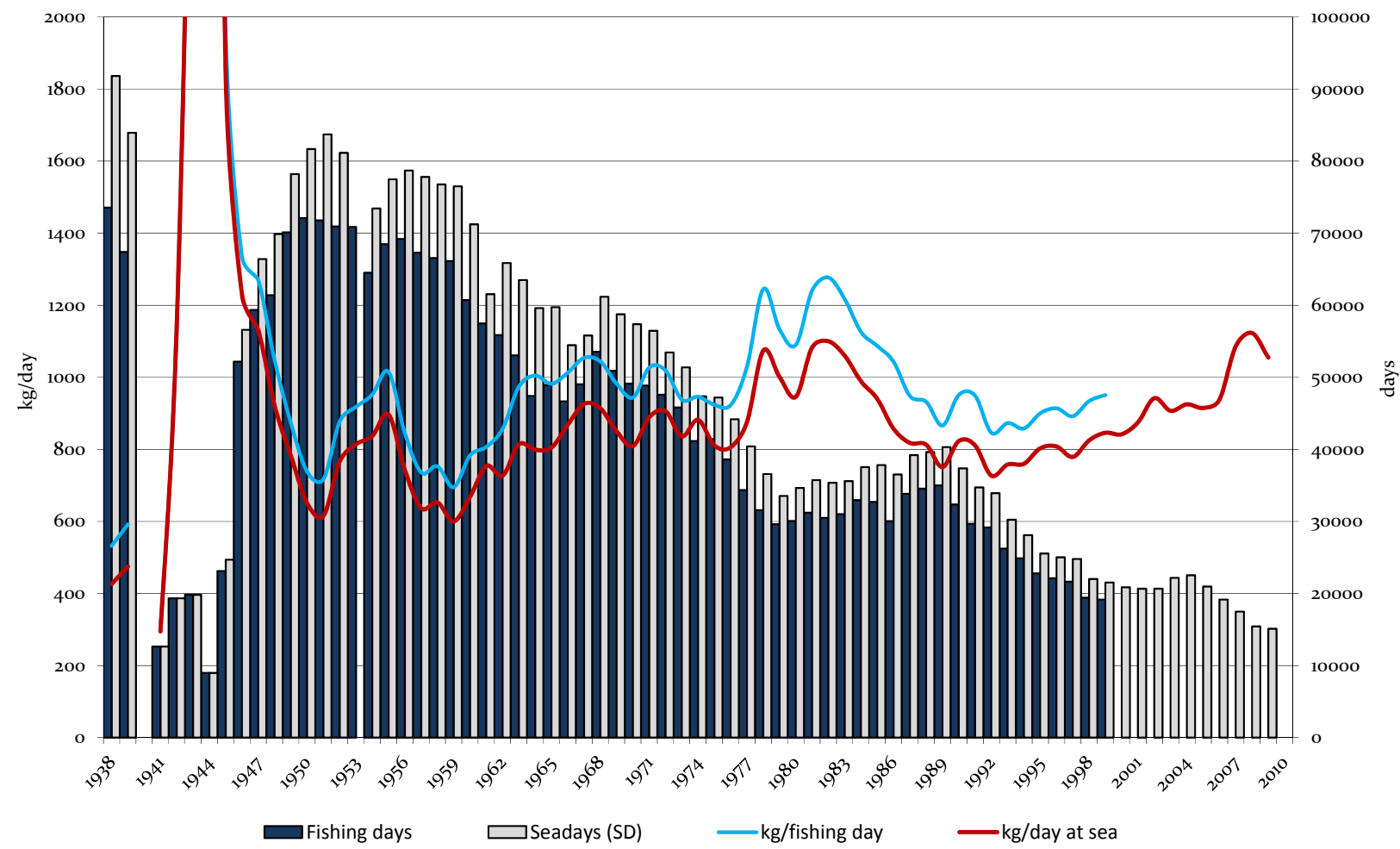

Figure 5.7.: Trend in total number of days spent at sea or fishing by the Belgian fishing fleet 1938-2010 (left axis). Reported landings of fish per day by the Belgian fishing fleet 1938-2010 ( $\mathrm{kg} /$ day, right axis). The extremely high values $\mathrm{kg} / \mathrm{day}$ in $1943-$ 1945 are not visualized to optimize scale (see text). Source: VLIZ HiFiDatabase, reconstructed from historical sources Table 5.1.

Considering the entire period - excluding WWII - an average of $850 \mathrm{~kg}$ fish were landed per day spent at sea. In 1942-1943 this was 5,500 kg per day (Lescrauwaet et al. 2013 under review). The average amount of fish landed per day in 2008-2010 (1,000 kg, Figure 5.7.) was similar to that in 1978-1983 and 1946-1947 (the peak years of landings for Belgian fisheries since 1929). These values however are not indicative of relative abundance of fish due to the shifts made by the Belgian fleet in targeted species and fishing grounds on the one hand, and also because of the profound changes in the fleet size, capacity, engine power and fishing power of the vessels and fishing gear employed. Also, the average tonnage and engine power of vessels have increased 10 and 6 times respectively since 1938 and technology creep has not been accounted for in the figures presented here. 


\subsection{CONCLUSIONS}

The recovery and integration of historical data on the characteristics of the Belgian sea fisheries fleet allowed reconstructing time-series from 1830 until present. Time-series show a decrease in the current fleet size (-85\%) and overall kW engine power (-5\%) since 1946 and demonstrate that this smaller fleet compensated by more powerful vessels with a 10-fold increase in average tonnage and a six-fold increase in average $\mathrm{kW}$ per vessel. The present analysis is based on the aggregated data for all types of commercial vessels and fishing gear in Belgian fisheries and does not reflect changes in specific fisheries over time. As it is not straightforward to compare the fishing power or fishing effort between different fisheries, the available data on fleet and fishing effort need to be disaggregated by fishing 'métier' (i.e. the combination of target species, fishing gear, season and fishing areas) in order to develop an analysis of the trends in landings per unit of effort LPUE. In a next step, it is important to expand the current analysis to develop distinct indexes of LPUE for different fishing 'métiers' in Belgian fisheries (e.g. shrimp beam trawl fisheries in coastal waters, beam trawl fisheries for flatfish plaice and sole in the North Sea or in the western waters). As these indexes of LPUE are widely accepted as indicators of changes in fish stock biomass (Christensen et al. 2003, Myers and Worm 2003, Cardinale et al. 2009a and 2009b, Thurstan et al. 2010) they can support current fisheries management and provide reference points for the definition of good environmental status in the context of the European Marine Strategy Framework Directive.

The time-series built a unique view of 180 years of dynamics of the Belgian sea fisheries fleet and its response to some of the major local events and international trends. It also demonstrated the significant changes in the fleet as a consequence of the introduction of new technologies (steam engines, motor engines), legislation (subsidies, tax levies, exclusion zones) and its responses to changes in the availability of fishing resources (target species and fishing areas). Some of the most drastic changes, such as the transition from sail and steam engines to motor engines or the shift from otter trawl to beam trawl as main fishing gear, took place over a time interval of one decade. This reflects the difficult conditions in which fisheries operate, but also suggests that the sector is able to adapt to quickly changing economic, technological and environmental conditions and newly emerging societal challenges. The time-series is unique in revealing how the decline in the fleet size - less ships concentrating in a few ports with specialized facilities - is linked to the disappearance of numerous fishing communities both along the coast and along the estuary of the river Scheldt, drastically changing the sight and social fabric of the coastal communities in Belgium. It also raises the question of whether a minimum fleet size should be observed to ensure economic viability and resilience of the sector, a question that is also of particular strategic importance to smaller EU fishing nations.

\section{ACKNOWLEDGEMENTS}

The authors thank all who contributed to the HiFiData project by digitising data, archiving historical documents, and by supporting the development of web applications (J. Haspeslagh, H. Lust, L. Lyssens, A. Scholaert). Their contributions are acknowledged on the Internet webpages of the HiFiData project. P. Rogiest (Heritage Library Hendrik Conscience Antwerpen, Belgium), M. Vandermaesen, F. Strubbe and L. Vandeweyer (State Archives Belgium), provided expert assistance with the Archives. Prof. F. Volckaert (Catholic University of Leuven, Belgium), H.Polet (Institute of Agriculture and Fisheries Research-ILVO, Flanders), E. Tessens and M. Velghe (Sea Fisheries department, Flanders), W. Versluys (company owner), provided valuable references and expert advice and the comments of two anonymous reviewers improved the quality of this manuscript. 